\title{
Heterologous in vitro Synthesis of Lens $\alpha$-Crystallin Polypeptide
}

MeSSENGer RNAs coding for $\alpha$ and $\beta$ globin chains ${ }^{1}$, for myosin $^{2}$ and for the mouse immunoglobin light chains ${ }^{3}$ have been shown to be translated in a reticulocyte cell-free system. Messengers are also translated faithfully in the ascites tumour cell-free system ${ }^{4}$ and in oocytes from Xenopus laevis 5 .

We stressed earlier ${ }^{6}$ that the lens is a unique tissue for the study of protein biosynthesis in vitro as it produces a class of highly specific proteins: the crystallins. $\alpha$-Crystallin, which

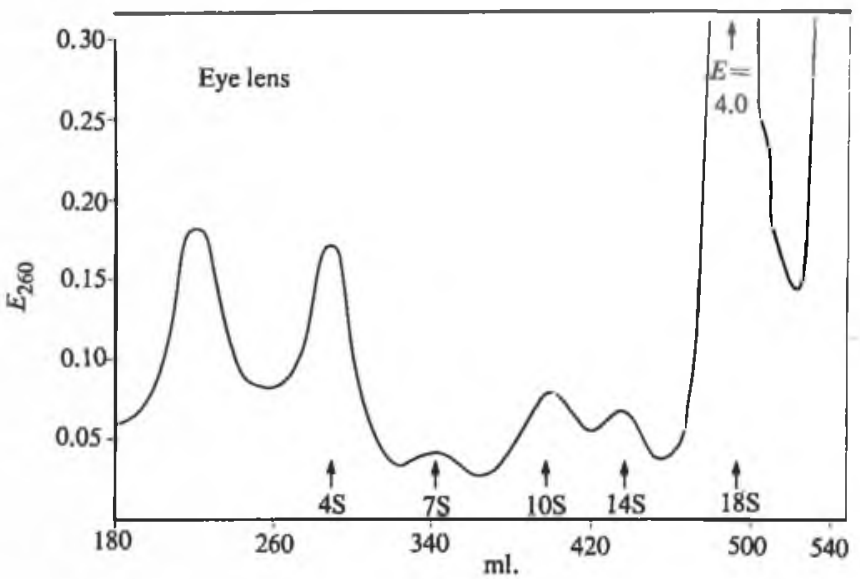

Fig. 1 Sedimentation profile of lens mRNA. Lens polyribosomes were suspended in a medium containing $6 \%$ sucrose

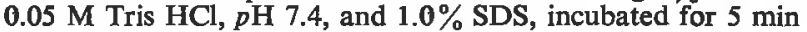
at $37^{\circ} \mathrm{C}$ and diluted twice with the same medium in which SDS was omitted. The RNA was separated by zonal centrifugation using an exponential gradient from 8 to $28 \%(w / w)$ sucrose. All sucrose solutions were pretreated by boiling with $0.02 \%$ diethylpyrocarbonate for $30 \mathrm{~min}$. The samples were applied in a volume varying from 10 to $25 \mathrm{ml}$., containing about $3 \mathrm{mg} / \mathrm{ml}$. polyribosomes. Routinely an overlayer of $200 \mathrm{ml}$. was used. Centrifugation was performed at $2^{\circ} \mathrm{C}$ in an IEC B $\mathrm{XXX}$ zonal rotor for $15 \mathrm{~h}$ at 50,000 r.p.m. The profile was monitored at $260 \mathrm{~nm}$ in a Gilford spectrophotometer adapted with a $2 \mathrm{~mm}$ flow cell. The RNA fractions corresponding to $7 \mathrm{~S}, 10 \mathrm{~S}$ and $14 \mathrm{~S}$ were precipitated with one-tenth volume of $2 \mathrm{M}$ potassium acetate $p \mathrm{H} 5.0$ and 2.5 volumes of ethanol for $16 \mathrm{~h}$ at $-20^{\circ} \mathrm{C}$. The precipitates were collected by centrifugation and dissolved in distilled water. 


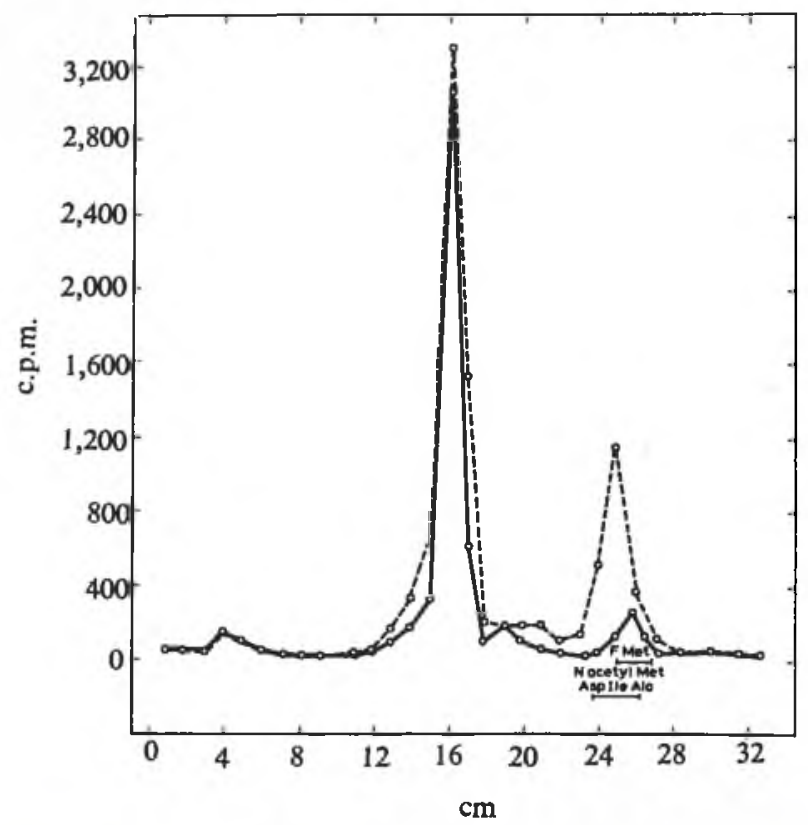

Fig. 2 Characterization of $\mathrm{N}$-terminal peptides. The incubation mixture was as described by Lockard and Lingrel ${ }^{1}$. Messenger RNA was added in a concentration of $20 \mu \mathrm{g} / \mathrm{ml}$. Incubations were performed at $37^{\circ} \mathrm{C}$ for $75 \mathrm{~min}$ in the presence of $0.5 \mu \mathrm{Ci}$ formyl ${ }^{35} \mathrm{~S}$ Met-tRNA ${ }_{t}^{\mathrm{Met}}$. After incubation $50 \mu \mathrm{l}$. of $0.25 \mathrm{M}$ EDTA, $20 \mathrm{\mu g}$ pancreatic RNAase and $300 \mu \mathrm{g}$ carrier $\alpha$-crystallin were added per $\mathrm{ml}$. and incubation was continued for $0.5 \mathrm{~h}$ at $37^{\circ} \mathrm{C}$. A $0.5 \mathrm{ml}$. aliquot of this mixture was precipitated with $5 \%$ trichloroacetic acid (TCA) washed three times and the TCA removed from the sediment with acetone. The $\mathrm{N}$-terminal peptides were obtained by incubating the precipitate with $500 \mu \mathrm{g}$ subtilisin in $2 \mathrm{ml} .0 .1 \mathrm{M}$ ammonium bicarbonate at $37^{\circ} \mathrm{C}$ for $6 \mathrm{~h}$. If no complete solubilization of the precipitate occurred a second subtilisin treatment was performed, $1.5 \mathrm{ml}$. of a 'Dowex 50' suspension was added and the mixture centrifuged. The supernatant was removed and the resin was washed with $2 \mathrm{ml}$. of distilled water. After centrifugation the two supernatant fractions were combined and lyophilized. The peptides excluded from the 'Dowex 50' were dissolved in $50 \mu \mathrm{l}$. distilled water and $10 \mu \mathrm{l}$. was used for high voltage electrophoresis. Electrophoresis was performed on 'Whatman $3 \mathbf{M M}^{\text {' }}$ paper at $p \mathrm{H} 6.5$ for $2 \mathrm{~h}$ at $35 \mathrm{~V} / \mathrm{cm}$. Strips of $1 \mathrm{~cm}$ were cut out and radioactivity was counted in a liquid scintillation counter using a toluene based scintillator. Reference peptides were stained for methionine using platinic iodide. $\mathrm{O}-\mathrm{O}$, Distribution of radioactivity without mRNA; $\mathrm{O}-. . \mathrm{O}$, distribution of radioactivity with added mRNA. 


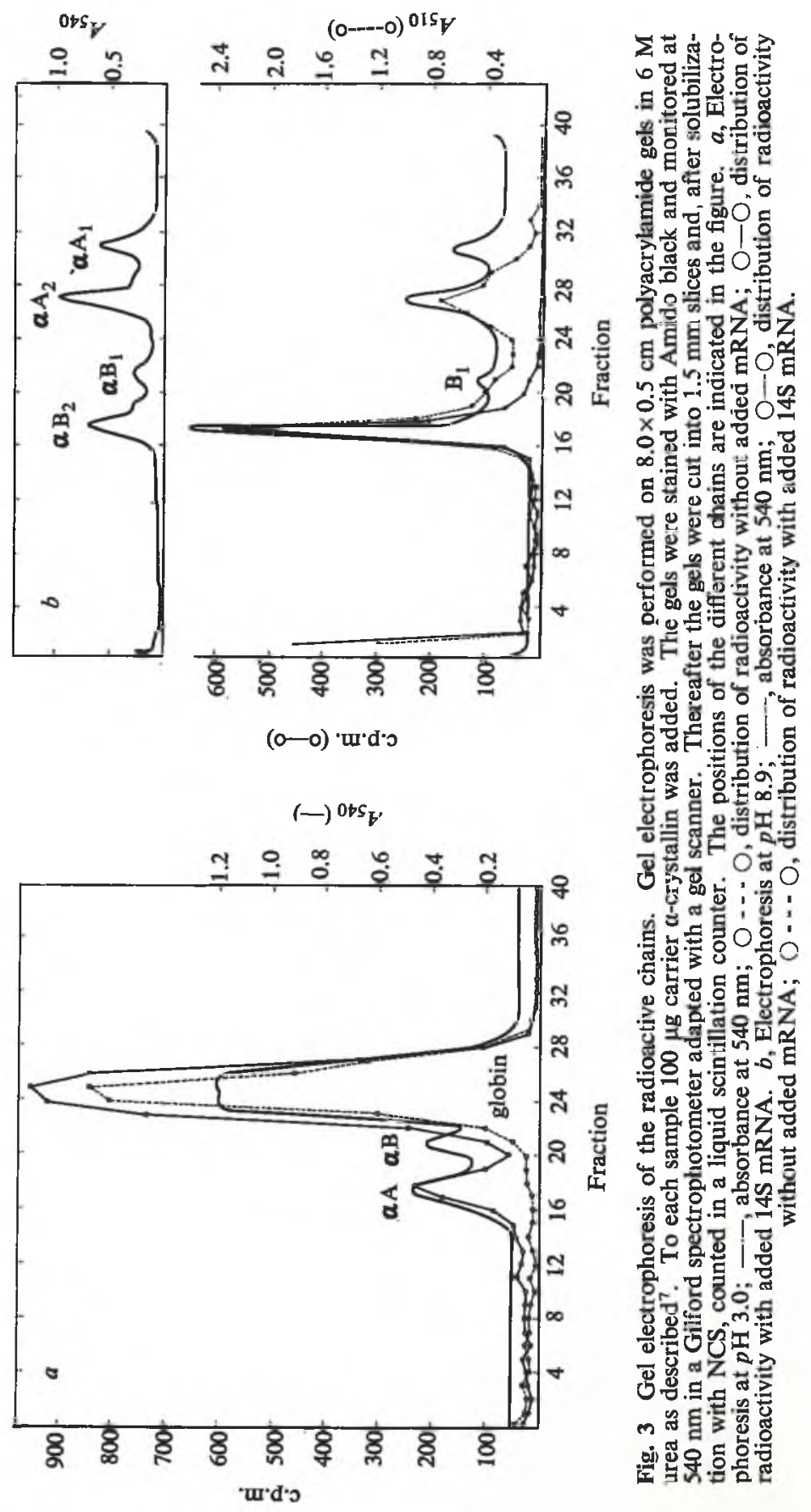


comprises about $35 \%$ of the total protein content, is composed of only four polypeptide chains designated $\alpha \mathrm{A}_{1}, \alpha \mathrm{A}_{2}, \alpha \mathrm{B}_{1}$ and $\alpha B_{2}$ of which $\alpha A_{2}$ is the major component ${ }^{7}$. We have isolated two mRNA fractions from bovine lens polyribosomes and one of these fractions codes for the synthesis of $\alpha A_{2}$ in a cell-free reticulocyte system. The newly formed polypeptide was identified by electrophoresis in acidic and basic urea gels, in SDS gels and by analysis of the N-terminal peptides. Both the lens mRNA fractions can be translated in the Krebs ascites cell-free system ${ }^{8}$.

Polyribosomes which were isolated from bovine lens, as described earlier ${ }^{9}$ were the source of $10 \mathrm{~S}$ and 14S mRNA preparations. The resolution achieved after zonal centrifugation is shown in Fig. 1. As all crystallin polypeptide chains have molecular weights of 19,000 to $25,000^{10.11}$, the 10S and 14S RNAs might represent the messengers coding for these polypeptide chains. RNA with a sedimentation value of about $10 \mathrm{~S}$ and $14 \mathrm{~S}$ can also be extracted from $16 \mathrm{~S}$ and $21 \mathrm{~S}$ ribonuclear protein (RNP) particles prepared by dissociation of the lens polyribosomes by EDTA treatment. Moreover, 10S and 14S RNA have base compositions clearly different from lens ribosomal ${ }^{6}$ and $\mathrm{tRNA}^{12}$. We shall describe here only the $14 \mathrm{~S}$ used as a source of mRNA.

A lysate system of rabbit reticulocytes prepared according to Lockard and Lingrel ${ }^{1}$ was used. Addition of lens messenger to this system resulted in a significant inhibition of the total amino-acid incorporation. As about $60-75 \%$ of the newly formed chains in organ culture are $\alpha$-crystallin chains ${ }^{13}$ and all chains of $\alpha$-crystallin contain $\mathrm{N}$-acetyl-Met-Asp-Ile-Ala at the $\mathrm{N}$-terminus ${ }^{14}$, we analysed the $\mathrm{N}$-terminal peptides of the in vitro products. Since we could not expect N-terminal amino-acetylation in the rabbit reticulocyte system, ${ }^{35} \mathrm{~S}$ MettRNA $_{t}^{\text {Met }}$ (derived from lens tissue and formylated with the aid of a crude $E$. coli enzyme preparation ${ }^{15}$ ), was used as radioactive precursor. Formyl-Met-tRNA ${ }_{f}^{\text {Met }}$ donates formylMet for the N-terminal sequence formyl-Met-Asp of $\alpha$-crystallin polypeptides in a lens lysate ${ }^{15}$. The electropherogram in Fig. 2, shows that addition of the 14S RNA to the cell-free system resulted in a radioactive spot located at a position identical to formyl-Met-Asp-Ile-Ala. Pronase digestion of this material released a peptide with an electrophoretic mobility identical to formyl-Met-Asp. Deformylation of the latter compound resulted in a peptide with the characteristics of Met-Asp.

We conclude that addition of the 14S RNA to the lysate results in the formation of polypeptides with an $\mathrm{N}$-terminus identical to $\alpha$-crystallin polypeptide chains. Since all four $\alpha$-crystallin polypeptides have this $\mathrm{N}$-terminal sequence, this 
analysis does not allow any conclusion concerning the type of polypeptide chains synthesized. Moreover it does not provide evidence for the completion of the chains. For this reason gel electrophoresis on basic and acidic urea gels and on SDS gels was carried out with the biosynthetic product.

Electrophoresis of the biosynthetic product on acidic urea gels (Fig. $3 a$ ) reveals that $\alpha \mathrm{A}$ polypeptides and no $\alpha \mathrm{B}$ chains are synthesized as no significant radioactivity is located in the $\mathbf{\alpha} \mathbf{B}$ region of the gel. Electrophoresis on basic urea gels (Fig. $3 b$ ) indicates that of the $\alpha \mathrm{A}$ polypeptides only the $\alpha \mathrm{A}_{2}$ chain is synthesized. To obtain an estimate of the molecular weight of the product, slices of the alkaline urea gels were subjected to SDS gel electrophoresis. The segments containing the globin and $\mathrm{B}$ chains and the segments corresponding to the $\mathrm{A}_{2}$ chains were applied to $15 \%$ acrylamide gels in $0.1 \%$ SDS. From the gel patterns it can be deduced that the molecular weight of the radioactive material originating from the $\alpha \mathrm{A}_{2}$ band is approximately 19,000 , which is identical to the molecular weight of the native $\alpha \mathrm{A}$ polypeptides ${ }^{16}$. Electrophoretic separation of the mixture containing $\alpha B$ and globin on SDS gels revealed that no detectable radioactivity is located in the $\alpha \mathrm{B}$ region. These findings in combination with the $\mathrm{N}$-terminal analysis clearly indicate that the $14 \mathrm{~S}$ mRNA isolated from calf lens polysomes directs the synthesis of a lens polypeptide chain in a heterologous system. It is worth mentioning that a messenger from a highly differentiated organ as the lens can be translated faithfully in a reticulocyte lysate of another species. This in combination with the observations of other authors indicates that, even in a highly differentiated cell, mRNA recognition factors do not exhibit stringent tissue specificity as suggested by Heywood ${ }^{17}$.

Quite remarkable is the fact that a mRNA of $14 \mathrm{~S}$ with a molecular weight of about 360,000 , as estimated by the method of Boedker ${ }^{18}$ is required to direct the synthesis of a polypeptide of a molecular weight of only 19,000. Two possibilities may be considered.

(1) The messenger does contain untranslated regions of considerable length. The occurrence of large poly A pieces, as reported for Hela mRNA ${ }^{19}$, mouse ascites $m R N^{20}$ and globin mRNA ${ }^{21,22}$ is not very likely, however, as the AMP content of lens mRNA is extremely low ${ }^{6}$. (2) The $14 \mathrm{~S}$ lens mRNA might be bicistronic, either with repeating nucleotide sequences for $A_{2}$ or a sequence for $A_{2}$ and (an)other unknown polypeptide(s). This problem is under investigation.

Our experiments may also shed some light on the initiation of translation of lens crystallin mRNA. As an acetylated methionine occurs at the $\mathrm{N}$-terminal position of all $\alpha$-crystallin polypeptide chains, the following initiation mechanisms might 
be considered. (1) Initiation takes place with initiator tRNA ${ }_{t}^{\text {Met }}$ charged in vivo with $\mathrm{N}$-acetylmethionine. (2) The N-terminal Met is derived from Met-RNA ${ }_{t}^{\text {Wet. }}$. Cleavage is prevented by the nature of the adjacent amino-acid residue(s), which might determine the specificity of the splitting enzyme. Such a specificity has been reported for ribosome-bound leucine aminopeptidase in $E$. coli $^{23}$. An alternative explanation might be that a specific acetylation mechanism prevents the removal of the N-terminal methionine derived from Met-tRNA

The mRNA does code for a starting sequence Met-Met-Asp in which the first Met, derived from Met-tRNA ${ }_{t}^{\text {Met }}$ is removed in the usual manner and the second, derived from Met-tRNA ${ }_{M}^{\mathrm{Met}}$ is acetylated in a later phase.

The first possibility is unlikely as the presence of an acetylated Met-tRNA in lens tissue could not be demonstrated ${ }^{15}$. The third possibility may be excluded by our results, as no formylMet-Met-Asp was found at the N-terminus of the biosynthetic $\mathbf{A}_{2}$ chains. Therefore the acetylated $\mathrm{N}$-terminal methionine present in $\alpha$-crystallin polypeptide chains is derived from Met-tRNA $t_{t}^{\text {Met }}$. The same conclusion could be drawn from initiation studies in a lens lysate system ${ }^{15}$.

Note added in proof: Meanwhile we were able to show that frog oocytes programmed with $14 \mathrm{~S}$ messenger also synthesize $\mathrm{\alpha A}_{2}$ chains. Berns, Kraaikamp Bloemendal and Lane, Manuscript submitted for publication).

This work was carried out partly under the auspices of the Netherland Foundation for Chemical Research and with financial aid from the Netherlands Organization for the Advancement of Pure Research. We thank Dr J. G. G. Schoenmakers for useful discussion and M. van Kraaikamp for technical assistance.
A. J. M. BERNS
G. J. A. M. Strous
H. BLOEMENDAL

Department of Biochemistry,

University of Nijmegen,

Nijmegen

Received September 9; revised November 5, 1971.

${ }^{1}$ Lockard, R. E., and Lingrel, J. B., Biochem. Biophys. Res. Commun., 37, 204 (1969).

2 Heywood, S. M., Cold Spring Harbor Symp. Quant. Biol., 34, 799 (1969).

3 Stavnezer, J.; and Huang, R. C. C., Nature New Biolgy, 230. 172 (1971).

${ }^{4}$ Mathews, M. B., Osborn, M., and Lingrel, J. B., Nature New Biology, 233, 206 (1971).

5 Gurdon, J. B., Lane, C. D., Woodland, H. R., and Marbaix, G., Nature, 233, 177 (1971). 
6 Berns, A. J. M., de Abreu, R. A., van Kraaikamp, M., Benedetti, E. L., and Bloemendal, H., FEBS Lett., 18, 159 (1971).

7 Schoenmakers, J. G. G., Matze, R., van Poppel, M., and Bloemendal, H., Intern. J. Protein Res., 1, 1 (1969).

${ }^{8}$ Mathews, M. B., Osborn, M., Berns, A. J. M., and Bloemendal, H., Nature New Biology, 236, 5 (1972).

9 Bloemendal, H., Schoenmakers, J. G. G., Zweers, A., Matze, R. and Benedetti, E. L., Biochim. Biophys. Acta, 123, 217 (1966).

10 Wisse, J. H., Zweers, A., Jongkind, J. F., Bont, W. S., and Bloemendal, H., Biochem. J., 99, 179 (1966).

11 Björk, I., Exp. Eye Res., 3, 254 (1964).

12 Virmaux, N., and Mandel, P., Nature, 201, 297 (1964).

13 Delcour, J., and Papaconstantinou, J., Lens Symposium Utrecht (1971).

14 Hoenders, H. J., van Tol, J., and Bloemendal, H., Biochim. Biophys. Acta, 160, 283 (1968).

15 Strous, G. J. A. M., van Westreenen, J., and Bloemendal, $H_{\text {, }}$ FEBS Lett., 19, 33 (1971).

16 Augusteyn, R. C., and Spector, A., Biochem. J., 124, 345 (1971).

17 Heywood, S. M., Proc. US Nat. Acad. Sci., 67, 1782 (1970).

18 Boedker, H., J. Mol. Biol., 35, 61 (1968),

19 Edmonds, M., Vaugham, H. M., and Nakazato, H., Proc. US Nat. Acad. Sci., 68, 1336 (1971).

${ }^{20}$ Lee, S. E., Mendecki, J., and Brawerman, G., Proc. US Nat. Acad. Sci., 68, 1331 (1971).

21 Lim, L., and Canellakis, E. S., Nature, 227, 710 (1970).

22 Burr, H., and Lingrel, J. B., Nature, 233, 41 (1971).

23 Matheson, A. T., Dick, A. J., and Rollin, G., Canad. J. Biochem., 48, 1292 (1970). 